\title{
Bir Alt Alan Olarak Köşe Yazarlığı ${ }^{*}$
}

\author{
Müge Neda ALTINOKLU ŞENAY
}

doktora öğrencisi, bilgi üniversitesi, siyaset bilimi nmugea@gmail.com

\section{Abstract}

\section{On the columnist practice as a subfield}

In the article, the differentiation process of columnist practice having the highest position within the journalistic field especially since the economic transformation of 1980s is primarily discussed within the framework of the criterions such as position of the practice, the degree and forms of competition, the conditions of production, the professional socialization mechanisms of agents and their degree of autonomy. The aim is not to offer an ideal definition of practice, rather to insist on its structural proprieties and make to understand it as a sub field. As a result, it is insisted that the particularities of the practice that gained through social and cultural capital constitute at the same time the problematical side of the practice. The article is based on semi-structured interviews with 10 well-known political columnists.

keywords: columnist, column, differentiation, subfield

* Makale yazım sürecinde desteklerini esirgemeyen Samim Akgönül'e, Birol Caymaz'a ve Ömer Turan'a teşekkürü borç bilirim. 


\section{Résumé}

\section{Sur la pratique des éditorialistes comme sous-champ}

Dans l'article, le processus de differentiation de la pratique éditorialiste ayant une position la plus haute dans les hiérarchies journalistiques depuis la transformation économique des années 1980 est examiné dans le cadre des critères comme la position de la pratique, le degré et les formes de la compétition, les conditions de la production de l'information, les mécanismes de la socialisation professionnelles et le degré de l'autonomie. Le but est ne pas proposer une definition idéale mais d'insister sur les propriétés structurales de la pratique and faire le comprendre comme un sous-champ. Par conséquent, il est souligné que les particularités de la pratique acquises par le capital social et culturel constitue à la même fois le côté problématique de la pratique. L'article est basé sur les entretiens conduits avec 10 éditorialistes connus en Turquie.

mots-clés: éditorialistes, éditorial, différentiation, sous-champ

\section{Öz}

Makalede, 1980'lerden günümüze yaşanan ekonomik dönüşüm kapsamında medya hiyerarşisinde önemli bir konuma gelen köşe yazarlı̆̆ı pratiğinin farklılaşma süreci üzerinde durulmuştur. Bu farklılaşma, pratiğin alan içerisindeki pozisyonu, rekabet ilişkileri, bilginin üretim koşulları, faillerin sosyalleşme mekanizmaları ve pratiğin özerklik durumu gibi kriterler aracılığıyla aktarılmıştır. Çalışmanın amacı, köşe yazarlığı pratiğinin ideal tanımını ve özelliklerini sunmak değil, farklılaştığı noktalar üzerinde durarak, bu pratiği gazetecilik alanı içerisinde bir alt-alan olarak düşünmeyi sağlamaktır. Çalışmada ulaşılan sonuç, köşe yazarlığı alt-alanının, özellikle sosyal ve kültürel sermaye aracılığı ile sahip olduğu yapısal farklııkların, alana ait sorunların temelini teşkil ettiği ve bunun köşe yazısını tanımlamada belirleyici olduğudur. Araştırmanın sahası, siyaset alanında yazan, tanınmış 10 köşe yazarlarıyla yapılmış derinlemesine görüşmelere dayanmaktadır.

anahtar kelimeler: köşe yazarı, köşe yazıIı, farklılaşma, alt-alan 


\section{Giriş}

Köşe yazarlığını bir pratik olarak ele almak gazetecilik sosyolojisi açısından farklı bir çerçeve sunar. Türkiye'de köşe yazarlığına siyaset paradigması açısından bakmak mümkün olsa da, bu bakış açısı köşe yazarlığı kurumunu araçsallaştıran bir bakış açısıdır. Zira köşe yazarları veya köşe yazılarıyla ilgili yapıımış çalışmalar toplumsal bir meseleyi anlamak için yapılan içerik ve söylem analizlerinden oluşmaktadır", fakat köşe yazarlığını, özgün "mesleki" farklııkları açısından ele alan çalışma sayısı oldukça azdır². Bu makaleye esas oluşturan çalışma ise, medya sosyolojisi literatürüne bir katkı mahiyetinde olup, köşe yazarlığını bir altalan ve simgesel bir güç kurumu olarak ele almıştır. Makalede, kategorik olarak gazetecilik alanının bir alt-alanı olan fikir/yorum gazeteciliğinin alt-alanlarından birini oluşturan köşe yazarlığı pratiğinin yapısal farklııkları ve farklılaşma süreci üzerinde durulacaktır. Üzerinde durulacak asıl husus ise, köşe yazarlığı pratiğinin sahip olduğu sosyo-tarihsel özelliklerin ve yapısal farklılıkların, bu alana has sorunların temelini teşkil ediyor olmasıdır.

Hiç kuşkusuz, Türkiye'de medya sektörü veya gazetecilik alanı köşe yazarlığı pratiği olmadan düşünülemez. Fakat köşe yazarlığı pratiği birçok açıdan da diğer gazetecilik pratiklerinden ayrılmaktadır; bilginin üretim koşulları, faillerin haber kaynaklarıyla olan ilişki biçimleri, faillerin bilgi üretim sürecindeki rolleri, sosyalleşme mekanizmaları, pratiğin sahip olduğu simgesel güç ve özerklik derecesi gibi özellikler, köşe yazarlığını diğer gazetecilik pratiklerinden ayırmakta, ona farkı bir konum sağlamaktadır. Bu noktada diyebiliriz ki, köşe yazarlığı pratiğinin farklılaşmasında sosyal ve kültürel sermayenin yapısı, dağılımı ve etkileşimi çok önemlidir. Burada sosyal sermayeden kasıt, Bourdieu'nün konuyla ilgili tanımlarına referansla, tanışıklık ilişkileri ve sahip olunan toplumsal bağlantılardır. Kültürel sermaye ise eğitim, hüner, bilgi birikimi ve en genel anlamda sosyalleşme sürecine gönderme yapmaktadır. Araştırmanın çıkış noktası olan bu savı - köşe yazarlığının farklılaşmasında sosyal ve kültürel sermayenin belirleyiciliğini - tartışabilmek için 1980'lerde yaşanan ekonomik dönüşüme ve onun bir yansıması olarak köşe yazarlığı pratiğinin dönüşümüne bakmak gerekir. Zira sosyal sermaye yapısının ve dağılımının alan ve pratik

1 Bkz. Bilgin, Filiz (2003). Köşe Yazarlarının 11 Eylül Olaylarına Yaklaşımı. Yayınlanmamış Yüksek Lisans Tezi, Kocaeli Üniversitesi Sosyal Bilimler Enstitüsü. Bölükbaşı, İsmail (2002). Avrupa Birliği Sürecinde Farkıı İdeolojik Kamplardaki Gazete ve Köşe Yazarlarının Yaklaşımları Üzerine Bir İnceleme. Yayınlanmamış Yüksek Lisans Tezi, Ankara Üniversitesi Sosyal Bilimler Enstitüsü. Durna, Tezcan (2002). Türk Basını'nda Avrupa Birliği: Köşe Yazılarında Adaylık Sürecinin Sunumu (3-24 Aralık 1999). Yayınlanmamış Yüksek Lisans Tezi, Ankara Üniversitesi Sosyal Bilimler Enstitüsü. Ercan, Gülsüm Songül (2003). Gazete Köşe Yazılarında Dil Kullanımı: Kaçınmalar ve Cinsiyet Değişkeni. Yayınlanmamış Yüksek Lisans Tezi, Dokuz Eylül Üniversitesi Sosyal Bilimler Enstitüsü. Gösterişli, Mehmet Erdem (2002). Spor Gazeteciliğinde Nesnellik: Fanatik, Fotomaç Spor Gazeteleri ve Star Gazetesi Köşe yazıları İçerik Çözümlemesi. Yayınlanmamış Yüksek Lisans Tezi, Anadolu Üniversitesi Sosyal Bilimler Enstitüsü.

2 Bkz. Yüce E. (2007). Simgesel Seçkinler ve Habitus: Hürriyet Gazetesi'nde Köşe Yazarlığı, Ankara Üniversitesi, Sosyal Bilimler Enstitüsü. Yayınlanmış Yüksek Lisans Tezi, Ankara. 
içerisinde farklılaşma yaratmasının en temel nedeni bilginin üretim koşullarında yatmaktadır. Söz konusu farklılaşmanın bir diğer sebebi ise kültürel sermayenin yapısına bağlı olarak gelişmektedir. Özellikle faillerin sosyalleşme süreçlerinin - ki bunun aile, eğitim, mesleki tecrübeler gibi birçok değişkeni içerdiğini unutmamak gerekir - kültürel sermaye üzerinde belirleyiciliği vardır. Böylece, köşe yazarlığı altalanını şekillendiren habitus, sosyal ve kültürel sermaye yapısı ve birikim süreçleri aracılığıyla oluşur denilebilir. Bu yolla köşe yazarlığı kurumsallaşarak, medya alanında yapısal farklılıkları ve belli bir işleyiş mantığı olan bir alt-alana dönüşür. Kültürel ve sosyal sermaye aracılığı ile ekonomik sermaye birikimini arttıran köşe yazarları toplumsal düzeyde simgesel güç kazanırlar. Lakin çalışmanın ilerleyen kısımlarında altını çizeceğimiz gibi, köşe yazarlığının sosyo-tarihsel ve yapısal özellikleri aslında bu alanın doğrudan sorunları olarak karşımıza çıkmaktadır. Köşe yazarlığını farklılaştıran özelliklerinden bahsederken bu sorunlara da değineceğiz.

Buradan hareketle köşe yazarlığını tanımlamak gerekir, lakin bu tanımlama asla kategorize etmeyi içermemektedir, zira bu, köşe yazarlığının ve köşe yazarlarının kendi içinde sahip olduğu farklılıkları görmemize engel olabilir. Yine de kategorik bir atlama yapmamak için belirtmemiz gerekir ki, köşe yazarları medya alanının içerisindeki birçok yazılı ve görsel alt-alanda bulunabilmelerine rağmen, köşe yazarlığı asıl olarak fikir/yorum gazeteciliği alt-alanına ait bir pratiktir. Bu noktada, mevcut köşe yazısı tanımlarına bakmak gerekir, fakat köşe yazısı tanımı köşe yazarlığı pratiğinin bir özelliği olarak karşımıza çıkıp köşe yazarlığını açıklamak için yeterli değildir ${ }^{3}$, zira köşe yazarlığı özellikle Türkiye'de hem yazı hem fail odaklıdır. Köşe yazısı tanımlarına bakarsak, Emin Özdemir'in Edebiyat Bilgileri Sözlüğü'ndeki ve Yazınsal Türler kitabındaki köşe yazısı tanımları önemli niteliktedir fakat yeterli değildir. Özdemir'e göre köşe yazısı, "gazete ve dergilerin belli sütunlarında yayımlanan, güncel, toplumsal, kültürel gibi sorunlardan konusunu seçen, bunları kanıtlama kaygısı gütmeden işleyen kısa oylumlu, yoğun anlatımlı yazı türüdür" (Özdemir, 2002, s. 116). Özdemir diğer kitabında şöyle demektedir; köşe yazsının "konusu ve esin kaynağı güncel olaylardır. (...) Yayımlanmasından sonra yitip gider etkisi. Bir bakıma kalıcılığı olmayan yazılardır. Anlatımları da olabildiğince yalın ve yoğundur. (...) yazar kanıtlama, doğrulama yoluna gitmek zorunda değildir" (Özdemir, 1999, s. 124). Benzer bir tanım Reuters'in Handbook of Journalism (2008) kitabında da görülebilir. Tanıma göre en genel itibariyle köşe yazısı, belli bir argüman etrafında yeni bakış açıları sunan, partizan nitelikte olmayan, uzman gazeteciler tarafından kaleme alınan, okuyucu açısından açıklayıcı olan ve değerli addedilen bir yazı türüdür. Aynı şekilde Sam Riley, The American Newspaper Columnist (1998, s. 11) adlı kitabında köşe yazısını, yaklaşık 750850 kelimelik, günlük, haftalık gibi düzenli periyodlar aralığında yazılan, kısa ve kompozisyon özelliği taşımayan, gazetelerin belirli köşelerinde yayımlanan yazı türü olarak kavramsallaştırmaktadır. Bu tanımlar doğru olmakla beraber, belirtildiği

3 Bu kapsamda, ayrıntılı köşe yazısı tanımları için bkz. Dursun O. (2015), Köşe Yazarlığından Medya Filozofluğuna: Ertuğrul Özkök ve Ahmet Hakan'ın Köşe Yazıları üzerine bir inceleme, Hacettepe Üniversitesi Sosyolojik Araştırmalar E-Dergisi, Mart 2015, Erişim 4 Kasım 2016, http://www. sdergi.hacettepe.edu.tr/makaleler/KoseYazarligindanMedyaFilozofluguna-MART_2015.pdf 
gibi köşe yazarlığı pratiğinin tüm yapısal özelliklerini bize vermez, zira köşe yazarlığı sadece köşe yazısından ibaret değildir. Bu durumda, araştırmamız çerçevesinde bu tanımlara da ek olacak şekilde köşe yazarlığı ile ilgili şöyle bir tanım yapabiliriz; köşe yazarlığı, (1) tam zamanlı veya yarı zamanlı olabilen, (2) genel veya tematik bir olayın yorumlandığı ve tercihen olay hakkında görüşün ve pozisyonun, belli stratejiler ve kurallar çerçevesinde ortaya konulduğu, (3) spontane olan veya belli bir ön hazırlık içeren (4) faillerinin farklı haber kaynaklarından ve kişisel ilişkilerden beslendiği, (5) siyasi süreçleri ve kamuoyunu etkileme gücüne sahip, (6) kendi içerisinde de eskilik-yenilik, tanınmışlık-tanınmamışlık şeklinde hiyerarşik bir yapıya sahip olan, (7) medya alanı hiyerarşisinde ve diğer tüm alanlararası (interchamps) ilişkilerde değerli görülen/addedilen, fikir/yorum gazeteciliğinin bir alt pratiğidir. Köşe yazarlığının tanımında ortaya konulan bu özellikler, bu pratiğin aynı zamanda medya alanındaki farklılaşma biçimlerini ve köşe yazarlığı pratiğinin yapısal sorunlarını da içermektedir.

Araştırmayla ilgili birkaç noktanın altını çizmek gerekir. Araştırma tanınmış köşe yazarlarıyla yapılmış bir dizi derinlemesine görüşmeye dayanmaktadır. ${ }^{4}$ Görüşmeler Aralık 2012-Şubat 2013 döneminde yapılmış, araştırma kapsamında 10 tanınmış, siyasi gündem yazan köşe yazarıyla görüşülmüştür. Sadece iki köşe yazarıyla gazete mekânında görüşülmüş, diğer sekiz köşe yazarıyla gazete dışında görüşülmüştür. Köşe yazarları ulaşılması zor bir kitle olduğundan, örneklemimiz ilk etapta görüşülen köşe yazarlarının ve bazı akademisyenlerin kendi tanışıklıkları ve bağlantıları aracılığı ile oluşturulmuştur. Diyebiliriz ki köşe yazarlarının sahip olduğu sosyal sermaye, örneklemimizi oluşturmamızda basamak olmuştur. Tavsiye ve referansların ardından elde edilen bağlantılar, çalıştıkları gazetelerin siyasi görüşlerine, faillerin medyada görünürlüklerine ve kamuoyunu etkileme süreçlerindeki rol dağılımına göre örnekleme eklenmiştir. On ulusal gazeteden siyasi gündem yazan köşe yazarları ile görüşülmüştür. Yeni Şafak, Zaman, Haber Türk, Sabah, Radikal, Cumhuriyet bu gazetelerden bazılarıdır. Elbette spor, magazin, ekonomi, sağlık gibi konularda yazan köşe yazarları da vardır ve bunlar üzerine çalışmalar yapılması, köşe yazarlığına dair bütünsel bir bakış açısı sağlar. Fakat bu çalışma, yalnızca siyasi gündem ile ilgili köşelere sahip yazarlar üzerine yapılmıştır. Çalışmanın genelleme iddiası bulunmamakla birlikte, söz konusu çalışma medya sosyolojisi literatürüne katkı niteliğindedir.

4 Derinlemesine görüşmelerden yola çıkarak diyebiliriz ki, Türkiye'de köşe yazarlığının sahip olduğu simgesel güç ve konum, köşe yazarları tarafından içselleştirilmiş ve "yasalaştırılmış" bir meseledir. Dolayısıyla köşe yazarlarıyla ilgili yapılan "kamusal entelektüel", "kanaat önderi", "kamuoyu teknisyeni" veya "entelektüel elit" gibi tanımlamalar doğru olmakla beraber, bu çalışmanın pekiştirici/doğrulayıcı fakat öncelikli sonucu değildir. Zira görüşülen kişiler zaten köşe yazarlığını "entelektüel bir pratik" olarak tanımlamışlar ve bu durum, entellektüalite söyleminin failler tarafından ne derece içselleştirildiğini göstermektedir. Araştırma açısından ilginç olan ikinci nokta ise, köşe yazarlığı meselesinin, pratiğin kendi failleri tarafından dahi bir "anomali" olarak saptanmasıdır. Köşe yazarlığı pratiğini, gazetecilik pratiklerinden ayrıştıran veya farklılaştıran birçok faktör, köşe yazarları tarafından "bize özgü", "örneği yok" şeklinde yorumlanmıştır - ki köşe yazarlarının bu ifadesi tam olarak çalışmada bahsedilecek olan farklılaşma sürecine işaret eder. Bu noktada her ne kadar köşe yazarlığını olumlama ve eleştirme arasında bir çelişki meydana geliyor olsa da, aslında köşe yazarlığı, failleri tarafından birçok açıdan önemli addedilmektedir 


\section{Köşe yazarlığını bir "alt alan" olarak düşünmek}

Araştırmanın teorik çerçevesini oluştururken, Pierre Bourdieu'nün Sur la Télévision (2008)'da geliştirdiği "gazetecilik alanı" kavramından yola çıkılmıştır. Bourdieu'nün Fransız gazetecilik alanı üzerinde yazdıkları radikal bir medya eleştirisidir, fakat Bourdieu'nün edebiyat ve sanat alanıyla ilgili çalışması (The Field of Cultural Production, 1993) veya akademik alana ilişkin yaptığı çalışma (Homo Academicus, 1988) dahil benzer çalışmalarda ortaya koyduğu gibi, bu çalışmada da temel ve ortak olan mesele, kültürel üretim alanlarının değişen pazar koşullarına nasıl boyun eğdiği ve buna göre nasıl şekillendiğiyle ilgilidir. Köşe yazarlığını da bu mantıkla ele almak mümkündür, fakat başlı başına bir alan olarak düşünmek yerine, bir alt-alan (sous champ) olarak düşünmek faydalı olabilir.

Bilinen bir gerçek olarak, Türkiye'de köşe yazarlığı birçok açıdan rutin ve klasikleşmiş gazetecilik pratiklerinden ayrılmaktadır. Bu alt alanı diğer medya pratiklerinden farklılaştıran sebepler hiç kuşku yok ki bilginin üretim koşulları ve stratejileri, faillerin gazetecilik alanıyla kurduğu ilişki ve toplumsal varoluş biçimleridir. Aslında köşe yazarlığı pratiğini bir alt-alan olarak ele almamızın nedenleri, alan kavramına ilişkin yapılan tanımlamalarda gizlidir. Eğer alan kavramını Bourdieu'yü takiben, genel yasalar çerçevesinde yapılandırılmış, sermaye biçimlerine bağlı olarak şekillenen ve güç ilişkileri kapsamında düşünülmesi gereken, her failin farklı çıkar peşinde koştuğu ve farklı varolma stratejileri geliştirdiği bir evren olarak tanımlarsak (Bourdieu, 2008, s.46, 2002, s.113), köşe yazarları evreninin de benzer şekilde tanımlanabilmesi pekâlâ mümkündür. Zira her bir alt-alan, aslında alanı içerisinde, alanıyla aynı mekanizmada işleyen mikro bir alandır (Marchetti, 2002, s. 24).

Bir gazetecinin veya bir medya kuruluşunun konumunu anlayabilmek için gazetecilik alanının içerisinde bulunan, mikro kozmoslar şeklinde işleyen ve birbiriyle bağlantılı olan alt-alanların pozisyonlarını dikkate almak gerekir (Bourdieu, 2008, s. 44). Bu açıdan bakıldığında, nasıl ki gazetecilik medya alanının bir alt-alanını oluşturuyorsa ve adliye, spor, siyaset-gündem, ekonomi, magazin gazeteciliği, gazetecilik alanının birer alt-alanını oluşturuyorsa, köşe yazarlığı da pekâlâ fikir-yorum gazeteciliğinin kendi öz mantığı ve yasaları olan bir alt-alanı olarak tanımlanabilir. Ayrıca gazetecilik alanının geniş ölçekte bir kültürel üretim alanı olduğu düşünüldüğünde ve köşe yazarlığı pratiğinin diğer toplumsal alanlarla olan ilişkisi de göz önüne alındığında, bu alt-alanın da belli ölçüde simgesel üretim gücüne sahip olduğu açıktır. Bourdieu'nün öğrencilerinden Dominique Marchetti, gazetecilik alanını oluşturan alt-alanları tanımlamak için bazı ilişkisel özelliklerden bahseder ki bu özellikler Türkiye'de köşe yazarlığı pratiğini de anlamamız için oldukça anlamlıdır. Marchetti'ye göre, medya alanındaki konum, alanın sınırları dâhilindeki güç yapıları, iş birliği ve rekabet dereceleri, faillerin medya alanındaki hareketlilikleri, faillerin özellikleri ve mesleki sosyalleşme mekanizmaları (Marchetti, 1996, s. 24) bir alt-alanı, alanda üretilen bilginin şartlarını ve faillerin 
sahip olduğu sermaye yapılarını kavramımız açısından önemlidir. Bu özelliklerden yola çıkarak, köşe yazarlığını farklılaştıran etmenleri şu alt-başlıklar altında sıralayabiliriz: üretilen bilginin simgesel değeri, haber kaynaklarıyla kurulan ilişki biçimleri, pratiğin rekabetçi yapısı, faillerin sosyalleşme mekanizmaları ve faillerin görece özerkliği.

Üretilen bilginin simgesel değerinden kasıt, köşe yazısının biçim ve içerik olarak ne derece bağlama ve faile bağlı üretildiğidir. Haber kaynaklarıyla kurulan ilişki biçimlerine gelince, özellikle sosyal sermayenin bu noktada ne kadar etkili olduğu üzerinde durulacaktır. Pratiğin rekabetçi yapısı ise köşe yazarlarının özellikle gazetecilik alanındaki ayrıcalıklı konumları sebebiyle diğer faillerle arasındaki farklılaşmayı anlamamız açısından önemlidir. Faillerin sosyalleşme mekanizmaları olarak ele alacağımız alt başlık ise, kültürel ve sosyal sermaye aracılığı ile alanda konum sahibi olabilen ve sermayeleri aracılığıyla bu konumu yeniden üretebilen faillerin - köşe yazarlarının - eğitim, sosyal statü, sosyalleşme mekanları gibi özelliklerine değinecektir. Son olarak, faillerin görece özerkliği altbaşlı̆ında ise köşe yazarlığının müdahale sınırları ve faillerin stratejileri üzerinde durulacaktır.

\section{Üretilen bilginin simgesel değeri}

Köşe yazarlığını bir alt-alan olarak ele almamız, bu pratiğin farklılaşmasına zemin hazırlayan birçok özellikte gizlidir. Bu yapısal özelliklerden ilki pratiğin ürettiği bilgi, yani köşe yazısının yapısı ve bilginin simgesel değeriyle ilgilidir. Burada bilginin simgesel değerini belirleyen köşe yazarının sahip olduğu simgesel sermayedir. Simgesel değerler bütünü şeklinde de ifade edilebilecek olan simgesel sermaye aslında Bourdieu'ye göre her türden sermayenin aldığı biçimdir (Bourdieu, 1995a, s. 116-117), zira simgesel sermaye, ekonomik, toplumsal ve kültürel sermayelerin algı kategorileriyle (bilişsel düzeyde) kavranmasıyla ortaya çıkar. Bu durumda köşe yazarının sahip olduğu simgesel sermaye, köşe yazısının simgesel değerini yani algı kategorileriyle kavrandığındaki değerini de etkilemektedir.

Türkiye'de köşe yazısı "en iyisinden" bir düşünce yazısı - "article d'opinion par excellence"(Martin-Lagardette, 1994) - olarak addedilebilir, çünkü köşe yazıları genelde basit bir yorum içermez. Köşe yazısındaki yorum, onu yazan aktörün simgesel gücüne ve alandaki pozisyonuna göre değerli bir yorum haline dönüşebilir ya da dönüşmeyebilir. Köşe yazısı, gazete yazı türleri arasında öne çıkan bir türüdür (Dubied ve Lits, 1997), fakat yazıya atfedilen bu önem, yazarının sahip olduğu konumun simgesel gücüne, yazarın sahip olduğu ve bağlı olduğu yayın organının sermaye yapısına ve yazarın retorik gücüne bağlı olarak değişir. Dolayısıyla yazının kamusal ve simgesel gücünü belirleyen köşe yazarının sahip olduğu kültürel ve sosyal sermayelerin yapısı ve derecesidir. Özellikle de siyasi gündem yazan köşe yazarları için haber kaynaklarıyla kurulan ilişki, sahaya 
yakınlık/uzaklık, sosyo-profesyonel angajmanlar gibi birçok faktör yazının yapısını, içeriğini ve gücünü belirler. ${ }^{5}$

Köşe yazısı, bir yorum yazısıdır, fakat bu yazı türü sadece kişisel yorum içermez. Köşe yazıları arasında araştırmaya dayanan analitik yazılar da bulmak mümkündür, fakat sayıca fazla değildir. Zaten köşe yazılarının haftada ortalama 4-5 gün yazıldığı düşünüldüğünde, araştırmanın her an mümkün olamaması gibi bir sorun karşımıza çıkmaktadır. Fatih Altaylı'nın Haber Türk gazetesinde 02 Aralık 2009 tarihli yazısında belirttiği gibi “(...) Ancak gördüm ki, bizim memlekette haftada en az 5, hatta 6 gün yazmıyorsan, okur seni adam yerine koymuyor. Konuk yazar muamelesi görüyorsun. (...) Haftada 6 gün yazı yazmak insani değil. Zaten 6 gün yazsan da iyi yazı ya 1 tane çıkıyor, ya iki tane. Gerisi laf kalabalığı." Köşe yazarları tarafından da dile getirilen bu sorundan hareketle diyebiliriz ki köşe yazısı her zaman araştırmaya dayanmaz, zira araştırma yapmaya yetecek zaman sıkıntısı vardır. Araştırmanın her an mümkün olmadığı durumlarda ise yazının içeriği yazarının retorik gücüne ve tecrübesine bağlı olarak kişisel hassasiyetlere, gündem akışına, ilgi alanlarına göre şekillenebilir. Siyaset ve gündeme ilişkin araştırmalar yapan ve yazılar yazan Radikal yazarının belirttiği gibi; köşe yazısı içeriğinin ve biçiminin bir standardı bulunmamaktadır.

“Köşe yazarlarının bir bölümü, hepsi demeyeceğim ama, haber içeriyor. Mesela
ben şimdi yarın Hakkari'ye gideceğim. Pazar gününe kadar Hakkari, Van,
Diyarbakır gezeceğim. Konferans, kitap imzası için gidiyorum ama yazı günüme
denk gelecek. Ne yazacağım ben? Hakkari de ilginç bir şeyle ilgili olabilir. Ne
yazacağımı şuanda bilmiyorum ama konuyuaşağı yukarı biliyorum. Bu son süreç...
(Barış Süreci) İşte insanlar ne düşünüyor, ne yapıyor, ne ediyor. Hakkari'deki
isimsiz, anonim kişilerin gözünden yazmak enteresan. Biraz manzara tasviri
yaparım, sevdiğim bir coğrafya zaten. Bu, haber bir yanıyla da. Yani Hakkari halkı,
kamuoyu ne düşünüyor. Ama nerede yazacağım? Köşe yazımda yazacağım. Yarın
öbür gün, köşe yazısı yazarken, Hakkari, Van yazacağım ben. Yani köşe yazılarının
az bir bölümü haber içeriyor. Dolayısıyla birinci kriter haber, ikincisi analiz,
Türkiye'de çok başarılı yapılan bir iş değil. Analiz içeren ve haber içeren köşe
yazıları az. İkisini birden içeren çok daha az. Laf olsun torba dolsun hesabı köşe
yazarlığı çok. Köşe yazarlığının bir standardı olmadığı için böyle oluyor. Ama siz
repütasyonunuzu muhafaza etmek istiyorsanız gündemle ilişkide olmanız lazım.
Gündem yazmanız lazım. Başta dediğim gibi, ben fikir üretmiyorum, pozisyon

5 "Köşe yazısı nedir ?" sorusunun mevcut pratik içerisinde tanımlanabilmesi oldukça güçtür. Belki yorum yazısı, düşünce yazısı gibi tanımlamalar yapılabilir, fakat yaptığımız araştırmaya göre 19 ulusal gazetede yaklaşık 650-700 köşe yazarı bulunmaktadır. Örneğin Nuray Mert, Türkiye'de çok sayıda köşe yazarının bulunmasını "köşe yazarı enflasyonu" olarak nitelendirmiştir (Radikal, 26 Ağustos 2004). Bu sayı kadrolu ve sözleşmeli tüm alanlarda yazan köşe yazarı sayısıdır. Siyaset yazan köşe yazarları sayısı tam bilinmemekle beraber, bu köşe yazarlarının çoğunluğa sahip olduğunu söyleyebiliriz. Özellikle kitle gazetelerinde her alanda yazan köşe yazarları bulunmakta olup, çoğunluk siyaset yazan köşe yazarlarına aittir. Dolayısıyla köşe yazarlarındaki niceliksel çokluk, bir köşe yazısı tipolojisi çıkarmayı oldukça güç hale getirmektedir. (Konuyla ilgili olarak birçok köşe yazarının yazılarına referans verilebilir; Tunç, A. (2012). Köşe yazarları neden var?, Erişim: 23.05.2013, http://www.habervitrini.com/haber/kose-yazarlarinin-cogu- gereksiz-91851/. Tezel, M. (2 Mayıs 2008) İstanbul'da 400 köşe yazarı var, ya Amerika'da?, Hürriyet. Özkök, E (4 Mayıs 2014). Üç Bin Köşe Yazarı Varmış, Hürriyet. 
ve argüman üretiyorum. Pozisyon sahibiydim, pozisyonumu argümantasyonla besliyorum sürekli." (1. görüşmeci, 18 Şubat 2013)

Yapılan görüşmelerin akabinde, köşe yazısının üretim koşullarında belli bir standardizasyon olmadığı görülmüştür, bu sebeple çalışmanın başlarında verilen köşe yazısı tanımları aracılığı ile genelleştirme yapmak bizi hataya düşürebilir. Bu bağlamda, gazetecilik alanında üretilen bir bilgi olarak köşe yazısının tanımını yapmaya çalışırsak şöyle bir sonuca varıız; köşe yazısı, (1) yazarının konumuna bağlı olarak gelişen ve değerlenen, (2) öznel bir şekilde bir olayın yorumlandığı (3) belli söylem stratejilerinin kullanıldığı (3) farklı haber kaynaklarından ve kişisel ilişkilerden beslenen, (4) yazılı basın bilgi türleri arasında değerli görülen/ addedilen bir medya söylem/metni türüdür. Köşe yazarı aslında gazetede yazısının bulunduğu sütundan okuyucuya seslenerek argüman üretmeyi, böylece okuyucu etkilemeyi veya kendi kişisel pozisyonu üzerinden ikna etmeyi amaçlar. ${ }^{6}$ Bu süreç okuyucu için taraf belirleme sürecidir, çünkü okuyucu düşüncelerini paylaştığı yazarı okur, hatta köşe yazarına göre gazete bile değiştirebilir. Dolayısıyla köşe yazısı iki açıdan önemlidir, birincisi "habercilik pazarındaki" gazete satışlarını dahi etkileme gücüne sahip bir yorum türü olduğu için. İkinci ise, okuyucunun kendisini bağdaştırabileceği, düşüncelerine ortak bulabileceği bir yazınsal tür olduğu için.

\begin{abstract}
"Inssanlar farklı eğilimdeki köşe yazarlarını okuyup sıradan bir kanaate ulaşabiliyorlar ama bazı kişiler kendileri gibi olan köşe yazarlarını okuyorlar. Sadece bilgi aramıyorlar, ona eğilebiliyorlar, içleri rahatlayabiliyor, çünkü onların hislerine tercüman olmuş oluyor köşe yazarı. Bizde köşe yazarının gazeteye ağılık kazandırdığı düşünülür, politik bir duruş kazandırdığı düşünülür." (5. Görüşmeci, 29 Aralık 2012)
\end{abstract}

Dominique Marchetti, gazetecilik alanının ticari/genel kutup ve entelektüel/ uzman kutup şeklinde yapılandığını ve her gazetede üretilen bilginin aynı ağırlığa sahip olmadığını söyler (Marchetti, 2002, s. 35) ki bu gazete tirajlarından, televizyon reytinglerden de saptanabilecek bir şeydir. Bu bağlamda, bir köşe yazısının etki alanının, haberin etki alanıyla eş olması beklenemez. Özellikle ticari kutba yakın gazetelerde köşe yazısı üreten birinin etki alanı daha geniştir ve daha önemli addedilebilir. Fakat etki alanı geniş bir köşe yazarının ürettiği köşe yazıları aslında yalnızca gazete sütunuyla sınırlı değildir. Köşe yazarı, farklı medya alanları ve kanalları aracılığılla da söylemini ve konumunu yeniden üretebilmektedir. Bu açıdan bakıldığında, özel kanalların ve tartışma programlarının sayısındaki artış, köşe yazarlığının dönüşümünde çok önemli bir değişime işaret eder. Televizyon programları bu faillerin yalnızca tanınırlık/görünürlük derecelerini artıımamış, onlara aynı zamanda farklı toplumsal alanlarda ve alanlar arası "dolaşma"

6 Patrick Charaudeau, köşe yazısının iki ilkeye dayanabileceğini söyler: ya mantığına seslenerek ikna etmeye çalışır ya da duygularına seslenerek etkilemeye çalışır. Öznel olmasının sebebi, kişisel bir düşünce belirtebilmesidir fakat kişisel düşüncenin yanı sıra, belli argümanlar çerçevesinde ikna etmeye veya etkilemeye çalışması, köşe yazısını diğer bilgi türlerinden ayııır. CHARAUDEAU P. (2009) Identité sociale et identité discursive. Un jeu de miroir fondateur de l'activité langagière, Identités sociales et discursives du sujet parlant, L'Harmattan, Paris. 
(circulation), pozisyonlarını yeniden üretebilme ve köşe yazısıyla elde ettikleri etki alanını genişletebilme şansı da vermiştir, fakat öte yandan köşe yazarlığı pratiğinin saygınlığını aşındırmış, faillere yapılacak dış müdahale olasılığını arttırmıştır.

\section{Haber kaynaklarıyla kurulan ilişki}

Köşe yazarlığı pratiği, Osmanlıdan günümüze basının gelişimine/ dönüşümüne paralel bir seyir izleyen, kökenini düşünce gazeteciliğinde bulabileceğiz bir gazetecilik pratiğidir. Geç Osmanlı dönemlerinden itibaren politik zihniyet yapılandırıcı rolü, aydınlatııı-öğretici otoritesi ve misyonuyla (Bora ve Cantek, 2009, s.881) var olmaya başlayan hem "dili dönen hem gücü yeten" (Ülgener, 1983) bir konuma sahip olan köşe yazarlığının, 1980'lerde Özal politikalarıyla beraber şekillenen hâli, her ne kadar birçok yapısal özelliğini de devam ettirse de, 1980 öncesi dönemlerden daha farklı bir tablo sunar. ${ }^{7} \mathrm{Ge}_{\mathrm{C}}$ Osmanlı dönemlerinden itibaren bürokratik elitlerle sosyalleşme ayrıcalığına sahip olan ve "kalem ustalıkları ve polemik maharetleri" ile yüksek gazeteci olarak addedilen köşe yazarları aslında üstlendikleri "muharrer" rolüyle Batılaşma sürecinin de önemli bir parçasını teşkil etmişlerdir (Bora vd. 2009, s. 880-884). 1980 sonrasında medya sahiplik yapısındaki değişim ve basın ilkelerinin neoliberalizme terki ile ortaya çıkan yeni medya tavrı ise, gazetecilik alanında yarattığı dönüşüm bir yana, köşe yazarlığı pratiğinin de alan içerisindeki hali hazırda "yüksek" olan konumunu pekiştirmesini sağlamıştır. İş ve devlet adamlarıyla geliştirilen yeni tip ilişkiler, gerek tartışma programlarıyla artan toplumsal tanınırlık, köşe yazarlığı pratiğinin ayrıcalıklı olan konumunu pekiştiren başlıca nedenlerdendir. Zaten sahip oldukları kültürel sermaye açısından farklı bir sınıflandırma içerisinde olan köşe yazarlarının, bu dönüşümün de etkisiyle konumlarını toplumsallaştırarak ve kurumsallaştırarak, simgesel bir kuruma dönüştürdügüne şüphe yoktur.

Köşe yazarlığının 1980 ve 1990'daki hâline işaret eden Rıfat Bali'nin konuyla ilgili yazısı bu anlamda yol gösterici niteliktedir (Bali, 1999). Bali'nin bahsettiği, köşe yazarları arasında yükselen seçkinci dalga, 1980'lerden günümüze yavaş yavaş bir tavır haline gelmiştir. Köşe yazısı içeriklerinin yurt dışı seyahatlerine, tüketilen şaraplara ayrıldığı, köşe yazılarının değişen üretim koşullarının yanı sıra köşe yazarlarının iş ve devlet adamı camiasıyla kurduğu yeni tip ilişkiler de, köşe yazarlığının alan içerisinde yerleştiği seçkin konumu doğrular niteliktedir. Türkiye'de köşe yazarlığının gazetecilik alanı içinde ve ötesinde bir pratik olarak addedilmesinin sebepleri, yukarı da bahsettiğimiz gibi medya/siyaset/ekonomi üçlemesinin doğurduğu bir sonuçtur. Özellikle 12 Eylül darbesini takip eden yıllarda yükselen apolitik dalgayla beraber Amerikan tarzı bir kültürün, toplumsal hayata bulaşması, günlük pratiklerin, terimlerin de değişmesine yol açmıştır (Kozanoğlu, 1993). Ayrıca Tıııçın da belirttiği gibi, 1980 sonrası değişen medya sahiplik

7 Köşe yazarlığı tarihine ilişkin daha detaylı bilgi için bknz. Tanıl Bora-Levent Cantek, "Köşe Yazarlığındaki Değişim ve Politik Düşünce Vasatı", Modern Türkiye'de Siyasi Düşünce, Cilt:9, Dönemler ve Zihniyetler, 2009, Koloğlu, Orhan (1994). Osmanlı'dan Günümüze Türkiye'de Basın. İstanbul: Illetişim, Topuz, Hıfzı (2003). Türk Basın Tarihi. İstanbul: Remzi Kitabevi. 
yapısıyla farklı sermaye gruplarının gazetecilik alanına girişi, politikacılar ve medya arasında eskiden beri var olan ilişkinin yoğunlaşmasına sebep olmuştur (Tılıç, 2009). Görüşmecilerin de belirttiği gibi, Özal döneminde artan ve bir tavır haline gelen bu yeni ilişki biçimi - ki bu noktada sosyal sermaye kavramına başvurmak faydalı olacaktır- köşe yazarlığının dönüşümünde önemli bir rol oynamaktadır. Bourdieu'ye göre sosyal sermaye "az çok kurumsallaşmış olan karşılıklı arkadaş ve tanıma ilişkileriyle kurulmuş dayanıklı ağ ile ilintili gerçek veya potansiyel kaynakların toplamıdır"(Bourdieu, 1986, s. 249). Tanıdıklık ilişkilerine gönderme yapan sosyal sermayenin köşe yazarlığını tanımlamadaki önemi yadsınamaz, çünkü köşe yazarlarının sahip olduğu sosyal sermaye yapısı gazetecilik alanı dışında kazanılmış ilişkilere gönderme yapmaktadır.

“Bizim rahmetli Turgut Özal'ın katkısıyla kötü bir huy gelişti basında. Turgut Bey
1983 'te Başbakan olduğu zaman, askeri otorite ile ters bir konumdaydı. Kendi
iktidar konumunu güçlendirmek için medyayı çok ustaca kullandı ve bugüne
kadar yapılmayan şeyler yaptı. Gece saat 12'de açıp telefonu (Cumhurbaşkanlığı
sırasında da devam etti o) 'Kim? Başbakan arıyor', 'Beni mi arıyor?'. Işste köşe
yazarı ya da gazetenin genel yayın yönetmenini arıyor. 'Ne haber, ne yapıyorsun?
Ya bugünkü yazını okudum. O tam öyle değil. Ben sana bir anlatayım.' Şu bu. Bir
takım el altından haberler vermeye başladı, genel yayın yönetmenlerine ve çok
belli başlı, seçici davrandığı bir takım isimlere, köşe yazarlarına." (1. görüşmeci,
18 Şubat 2013)

"Bir diğer gelişme de 80 sonrasıdır. ANAP lideri Özal, gazetelerin yazarlarını yanına alıp dolaşmaya başladı. Muhabirler o dönemde, yani 80'lerde daha arka plana düşmeye başladılar, köşe yazarları ön plana çıkmaya başladı. Bu iş gazetelerin de kolayına geldi. Daha ucuza mal olan bir şeydi. Benim de öyle bir dönemim vardı. Başbakan uçağa binerdi. Biz de giderdik, konuşurduk ederdik. Önemli haberleri köşe yazarları yazardı. Gazeteler onu büyütürdü. Böyle bir dönem yaşandı ve gazetelerin her tarafından köşe yazarları sarkar hale geldi. Bugün de öyle, çok abartılı bir durum." (2. Görüşmeci, 7 Ocak 2013)

Köşe yazarlarının elde ettiği bu ayrıcalıklı konum, yalnızca medya/siyaset ilişkisinin bir sonucu değildir, aynı zamanda Tanıl Bora ve Levent Cantek'in de işaret ettiği gibi medyanın "süpermarketleşmesi" nin (Bora vd., 2009, s. 897) de yarattığı bir sonuç olarak düşünülmelidir. 1990'larda özel kanallarda hızla artan tartışma programları ve köşe yazarlarının programlara davet edilmesi, köşe yazarlarının görünürlüklerini ve ayrıcalıklarını arttırsa da, bu pratiği gün geçtikçe gazetecilik piyasası içerisinde araçsallaştırmıştır. Böylece, köşe yazarlığı pratiği, bir yandan toplum nezdinde simgesel gücünü ve meşruiyetini arttırıken, bir yandan da siyasi çevreler tarafından toplumu yönlendirme potansiyeli (veya siyasi atmosfere bağlı olarak, tehlike) olarak görülmüştür. Haber Türk gazetesi yazarının da belirttiği gibi, köşe yazarlığı pratiğindeki bu dönüşüm, gazetecilik özelinde mesleki bir sapma niteliğindedir:

"Ben metroya çok binen, sokakta dolaşan, otobüse binen biriyim. O kadar şöhret olmasan bile, halk biliyor resminden, gazeteden, arada televizyondan. Sana şaşırıyor insanlar ama anormal olan bunun şaşılacak bir hâle gelmesi. 
$\mathrm{Bu}$ ne demektir? Köşe yazarı bir star olmuş. Televizyon sayesinde bir aktör haline gelmiş ve kendisi haber olan insan haline gelmiş. Bunların hepsi çok yanlış, saçma. Bu meslekteki en önemli sapmalardan biri yani. Köșe yazarı çıkar televizyonda bir şey konuşur ama bizimkiler sürekli kavga eder, Türkiye'nin tek kamusal alan temsilcisi gibi davranır, neredeyse siyasetçidir... Meclisten kaç milletvekili tanırsınız? Köşe yazarları onlardan çok daha fazla tanınıyor sanki... Bu toplumun ana tartışma kanallarının en önemlileri parlamentodur, sivil toplumdur. Ama köşe yazarı, onların hepsini bastıran, çok hâkim, tahakküm eden bir aktör rolündedir." (3. Görüşmeci, 4 Ocak 2013)

Özellikle 1980 sonrası işlevsel ve yapısal olarak değişen gazetecilik alanı içerisinde köşe yazarlığı pratiğinin yükselişi, muhabirliğin/haberciliğin değersizleşmesiyle paralel seyretmiştir. Çünkü değişen medya koşullarının ekonomi politiği daha hızlı bir bilgi servisini, rekabeti, görünürlüğü ve tanınırlığı gerektirmektedir. Böylece gazetecilik, pazar koşullarında belli bir yabancılaşma sürecine girmiştir (Tılıç, 2009, s.386). Köşe yazarlığı pratiği de, gazetecilik alanı içerisinde belli bir yükselişe girmiş, yaygın basında gazeteler arasında köşe yazarı transferleri yapılmaya başlanmış, köşe yazarları gazetelerdeki fotoğrafları ve imzalarıyla kamusal birer figür haline gelmiş, köşe yazarlığı toplumsal bir tartışma mekanizması olarak gündelik pratikler içerisinde, tıpkı pratik siyasetin yarattığı etki gibi toplumsallaşmaya başlamıştır. Köşe yazarlığının toplumsallaşmasında sahip olduğu sosyal sermayenin yapısı ve dağılımı önemli bir rol oynamaktadır. Hem sahip olunan yeni haber kaynakları ve bununla beraber gelişen yeni tip ilişkiler, hem de gazetecilik alanının piyasaya tabi olmasıyla dışa açılmasının bir sonucu olarak görünür olmanın kaçınılmaz olması, özellikle köşe yazarlığının diğer gazetecilik pratiklerinden ayrılmasında önemlidir. Daha önce de belirtildiği gibi kültürel ve sosyal sermayenin yapısı ve dağılımı aracılığıyla şekillenen köşe yazarlığı pratiğini farklılaştıran etmenlere daha yakından bakmak için köşe yazarlığını bir alt-alan olarak düşünmek gerekir.

Köşe yazarlığını diğer gazetecilik pratiklerinden farklılaştıran en önemli özelliklerden biri şüphesiz ki sahip olunan haber kaynağı ağıdır. Köşe yazarlarının sahip oldukları kültürel ve sosyal sermaye biçimleri ve sosyalleşme mekânları, faillere farklı bir haber rezervi olanağı sunmaktadır.

"Türkiye'de gündem sıkıntısı yok. Gündemdeki konular da belli, hepsi de kamuoyunun çok dikkatini çeken konular. Onu bir defa kafanızda, zihninizde kararlaştırıyorsunuz, 'şu konuyu yazacağım' diye. Tabii bir birikim de var. 35 sene bir işin içerisinde olunca o birikime sahip oluyorsunuz... Kumaş olması lazım bir insanda. Onu tecrübeyle, bilgiyle, çalışmalarla geliştirirsiniz. Yazarda üslup da olması lazım. Bunların hepsi bir araya geliyor: tecrübe, kabiliyet, üslup. Çevre de çok önemli. Bizim yaşımız itibariyle bir çevremiz var. Türkiye'nin siyasetinde etkili olan, konuştuğumuz insanlar var. Mesela merak ettiğimiz bir şeyi onlara sorduğumuz zaman kafamızdaki bazı dügümler, bazı kilitler açııyor. Siz tabii o görüşmeyi hissettirmeden, o açılan pencereyi kendi kaleminizle değerlendiriyorsunuz. 25-30 yaşındaki bir insan çok kabiliyetli de olsa, böyle haber kaynakları yoksa sadece üslubunu konuşturur ama olayları değerlendirmede çok ilginç fikirler ortaya atması zor olur." (4. Görüşmeci, 4 Ocak 2013) 
Daha ayrıcalıklı, kolay ve hızı yollardan bilgi üretebilme, hem alan içi farklııklara yol açmakta, hem de köşe yazarlığı pratiğinin sahip olduğu imtiyazlı konumu pekiştirmektedir. Lakin buradaki tehlike, haber kaynağı tarafından yönlendirilme konusunda ortaya çıkar ki bu da köşe yazarlığı pratiğinin özerklik sorunuyla doğrudan ilişkilidir. Ayrıca belirtmek gerekir ki, sosyal ve kültürel sermaye birikiminin bir sonucu olarak gelişen haber kaynağı çeşitliliği, muhabir ve köşe yazarı arasındaki uçurumu derinleştirmekte, gazetecilik alanındaki çatışma noktalarından birini oluşturmaktadır.

\section{Pratiğin rekabetçi yapısı: bir mücadele alamı olarak köşe yazarlığı}

Köşe yazarlığı pratiği seçkin/imtiyazlı bir pratik olarak addedildiğinden, bu alanın ne kadar rekabetçi bir yapıya sahip olduğunun da üzerinde durulmalıdır. Burada rekabet ilişkisinin iki boyutu vardır; köşe yazarlarının kendi arasındaki rekabet ilişkisi ve köşe yazarlarının diğer faillerle ve alanlarla olan rekabet ilişkisi.

Bu çekişmeli ilişkinin en önemli nedenlerinden biri, köşe yazarlığının medyada görünürlügüyle ilgilidir. Örneğin Bourdieu, Televizyon Üzerine kitabında, simgesel şiddet üreten bir mekanizma olarak ortaya çıkan televizyonun dolaylı ve dolaysız yollardan ticari kaygılara boyun eğmesinin yarattığı etkiler üzerinde durarak televizyon programlarını eleştirir. Konuşma süresinin sınırlandırılması, içerik müdahaleleri gibi birçok sebepten ötürü, hızlı (fast thinkers) ve yönlendirilmiş tartışma programları sebebiyle televizyonu rekabet dolu bir alan olarak tanımlar (Bourdieu, 2008, s. 32-39). Televizyon ve köşe yazarlığı pratiği arasındaki ilişki de benzer bir ilişki doğurmuştur. Siyasi ve ideolojik sebeplerle tartışma programları yayından kaldırılan köşe yazarları veya tartışma programlarına artık davet edilmeyen köşe yazarları bu durumu örneklemektedir:

\footnotetext{
“Başbakanla iyiydim, sonra bir sürü konuda ters düştüm. Bir sürü televizyona program yapıyordum, para kazanıyordum. Şimdi çağırmıyorlar televizyona. Programlar iptal edildi, olanlar kaldırıldı. Mali bakımdan benim için büyük dezavantaj. Gayet iyi para kazanıyordum açıkçası. Şimdi kazanamıyorum. Bu iyi bir şey değil ama ifade özgürlüğüm kısıtlanıyor da değil. Burada (Radikal gazetesi) yazıyorum işte." (1. Görüşmeci, 18 Şubat 2013)
}

Gazetecilik alanı, tıpkı siyaset alanı, ekonomik alan, edebiyat alanı gibi bir güç ilişkisi alanıdır (Bourdieu, 2008, s. 46) ve bu ilişki televizyon kanalları veya gazeteler arasındaki ekonomik rekabetle sınırlı değildir. Alan içinde her bir aktörün de kendi konumunu korumak için geliştirdiği stratejiler ve stratejilerden doğan güç ilişkileri vardır. Bu Bourdieu perspektifi, bir alt-alan olarak köşe yazarlığı pratiğinin karşı karşıya olduğu pazar koşullarında yaşamda kalma süreci olarak düşünüleceği gibi, farklı bir ilişkiyi de düşündürtmektedir: köşe yazarları ve gazetecilik alanının diğer failleri arasındaki rekabet ilişkileri. Buradaki ilişki çok boyutlu olup, tüm failleri kapsayan bir gazetecilik sosyolojisi çalışmasında daha iyi anlaşılabilecektir. Bizim çalışmamız kapsamında ise, en çok göze çarpan mesele köşe yazarları ve muhabirler arasındaki ilişkinin boyutudur. 


\begin{abstract}
"Köşe yazarlığı gazeteciliğin en görünen yerlerinden bir tanesi. Dolayısıyla popülerlikle beraber gider. Yazarın yazdıkları kadar yazarın imajı da devreye girer. O imajın tüketilmesi de yazdıkları kadar tüketici açısından önemli olur. Dolayısıyla hem siyasallaştırılan hem metalaştırılan hem de popülerleştirilen biridir köşe yazarı. Gazeteciler içinde nerede durur? Köşe yazarları, gazeteci mesleğinin, gazetecilerin en az sevdiği kategoridir. Muhabirler, 'ası işi biz yapıyoruz, bu adamlar bunu yapıyor' duygusuyla yaklaşırlar. Nazlı oldukları için, problemli oldukları için her zaman yayın yönetmenlerinin hoşuna gitmez. Biraz ayrıcalıklı bir yer diyebilirsiniz. Ama zaman zaman çok taşıyıcıdırlar tabii gazeteler için. Bir muhabire kıyasla, bir köşe yazarının müdahale imkanları, temas imkanları çok daha fazla olabilir. Dolayısıyla yazılacak ya da herhangi bir yorum o gün gazeteyi kurtarabilir." (6. Görüşmeci, 3 Ocak 2013)
\end{abstract}

Köşe yazarlığı pratiği,içerisinde belli ilişkiler gerektiren ve bu ilişkilere bağlı olarak gelişen birtakım gruplaşmalar olduğu açıktır, ki bu çalışmanın sahasında da belli bir köşe yazarı ağından seçilen köşe yazarları ile görüşülmüştür. Dolayısıyla köşe yazarları da kendi içlerinde çatışmacı bir ilişki barındırır. Medya hiyerarşisinde "yüksek" bir konumda bulunan köşe yazarlarının da kendisine has bir hiyerarşik yapıya sahip olduğunu unutmamak gerekir. Sahip olduğu sosyal çevrenin köşe yazarlığı için önemini vurgulayan Zaman gazetesi yazarı da benzer şekilde köşe yazarlığına içkin hiyerarşik yapıyı doğrulamıştır.

\footnotetext{
"Türkiye'de köşe yazarları birbirleriyle fikir alışverişinde bulunmazlar. Her biri ayrı bir zirve olduğu için, zirveler birbirlerinden istifade etmezler. Birbirlerini pek okumazlar da." (4. Görüşmeci, 4 Ocak 2013)
}

Tanınmışlık, görünürlük, sosyal sermaye ve kültürel sermaye biçimleri, köşe yazarlarının kendi aralarınki ilişki biçimlerini de etkilemektedir çünkü her köşe yazarı aynı ilişki ağına veya kaynağına, medyada aynı görünürlüğe, eşit okunulurluk derecesine sahip değildir. Böylece, köşe yazarları arasında da aynı ilişki ağına sahip olanlar ve olmayanlar, eskiler ve yeniler, tanınmışlar ve tanınmamışlar şeklinde birçok gruplaşma görülebilmektedir. Bu bölünmüşlük ise köşe yazarlarını da hiyerarşik olarak kendi içlerinde ve medya alanı içinde sürekli yeniden yapılandırmaktadır.

\title{
Kültürel sermaye ve sosyalleşme mekanizmaları
}

Bir alt-alanın nasıl işlediğini anlamak için köşe yazısını üreten faillerin, yani köşe yazarlarının özelliklerini dikkate almamız gerekir. Özellikle yaş, eğitim durumu - kültürel sermayenin en önemli belirleyicisi olarak kabul görür - ve sosyal köken değişkenleri, hem köşe yazarlığı pratiğini tanımlamamız hem de pratiği gazetecilik alanı içerisinde konumlandırmamız açısından önemlidir. Yaş değişkeni veya "meslekte eskilik" meselesi, alt-alan içerisinde köşe yazarlarının pozisyonlarını belirleyen bir değişkendir. Özellikle "eski meslektaşlara duyulan özlem" veya "eski köşe yazılarının övülmesi" gibi durumlar, orta yaş üstü köşe yazarlarının, biriktirdikleri sosyal ve kültürel sermaye aracılığıyla daha prestijli bir konuma sahip olduğunu göstermektedir. 
İkinci değişken ise, eğitim durumuyla ilgilidir. Eğitim aynı zamanda önemli bir sosyalleşme aracı ve kültürel sermayenin ölçütlerinden en önemlisidir. Bourdieu'nün merkezi kavramlarından biri olan kültürel sermaye, inşa edildiği toplumsal uzamın yapısına bağlı olarak, politik sermaye, bürokratik sermaye, eğitimsel sermaye gibi farklı biçimlerde var olabilir (Bourdieu, 1986). Köşe yazarlığı pratiği için de eğitim düzeyinin belirlenmesi, yine bu pratiğin hangi noktada farklılaştığını kavramamızı sağlar, çünkü Bourdieu'ye göre eğitim kültürel sermayenin kurumsallaşmış halidir (Bourdieu, 1986, s. 16). Görüşülen köşe yazarları, iyi üniversitelerin siyaset bilimi, uluslararası ilişkiler, ekonomi gibi bölümlerinden mezunlardır. Görüşülen kişilerin biyografik özellikleri dışında, genel bir biyografi çalışması yapılırsa da, eğitim düzeyinin Türkiye ortalamasına kıyasla görece yüksek olduğu görülecektir. Zira bazı akademisyenlerin, sanatçıların bile köşe yazarı olduğu düşünülürse, ciddi bir kültürel sermaye birikimine sahip olunması köşe yazarlığı pratiğinin en önemli kıstaslarındadır. Unutmamak gerekir ki, Bourdieu'nün alan teorisinde sosyal sermaye, kültürel sermayenin artmasına, kültürel sermaye de sosyal sermayenin artmasına neden olur ve her ikisi de iktisadi sermayeyi besler. Benzer şekilde köşe yazarları açısından bakıldığında sanatsal, edebi ve akademik faaliyetlerde de bulunabilen köşe yazarları için, bu faaliyetler ve girdikleri sosyal ortamlar köşe yazarı olarak sahip oldukları pozisyonu güçlendirmek, iktisadi, sosyal ve kültürel sermaye birikimiyle simgesel güçlerini meşrulaştırmak için önemli görülmektedir.

Görüşülen köşe yazarları, köşe yazarlığını bir gazetecilik pratiği olarak tanımlamışlardır. Bu yüzden, köşe yazarlığı pratiği için gazetecilik eğitiminin gerekli olup olmadığı önem kazanmaktadır. Gazetecilik formasyonuna sahip az sayıda köşe yazarı olmasına rağmen, birçok köşe yazarı gazetecilik eğitimini önemli fakat yetersiz bir kriter olarak görmektedir, çünkü Türkiye'de gazetecilik eğitiminin oldukça sorunlu bir yapıya sahip olduğunu düşünmektedirler. Fakat bu çalışma kapsamında gazetecilik eğitiminin içeriği ve yapısı öncelikli konumuz olmadığı için bu konuyla ilgili bir tespit yapmak zordur. Konu burada biraz daha gazetecilik eğitiminden çok köşe yazarlığı alanının popülaritesi ve cazibesiyle ilgilidir. Gazetecilik eğitimi dışında, araştırma merakı, okuma sevgisi ve yazma kabiliyeti en önemli kıstaslar olarak belirtilmektedir. Ayrıca haberin kaynağıyla kurulan ilişki ve ilişkinin taşındığı mekân da köşe yazarının en önemli sosyalleşme aracıdır diyebiliriz. Dolayısıyla köşe yazarı olmak için gazetecilik formasyonu şart değildir, yani Bourdieu'nün deyişiyle alana giriş kriteri değildir ama iyi bir eğitim seviyesi ve buna ek olarak güçlü bir ilişki ağı ve ciddi bir kültürel sermaye gerekli görülmektedir.

\footnotetext{
"Gazetecilik formasyonu şart değildir ama muhakkak derli toplu bir ciddi formasyon sahibi olması gerekir bence. Herhangi bir alanda bir formasyona tâbi olmadan, temel genel kültür ve temel kültürün olmadan çok zordur." (7. Görüşmeci, 2 Ocak 2013)
}

“Bence tabii ki belli bir kültürel formasyon gerekiyor. Belli uzmanlık alanları da var. Ekonomi, yerel yönetimler, hukuk. Ama gazetecilik avukatlık, doktorluk, 
mühendislik gibi diplomanı alıp yapabileceğin bir iş değil. Bunun loncası, odası, barosu, tabip odası yok. Tabii ki gazetecilik eline bir iletişim aracı geçirip oradan ağzına geleni yazmak değil. Bence özel bir şey gerekmiyor. Ne gerekiyor? İyi okumak, merak etmek. Tabii ki çok temel şeyler var. Bana göre vicdan, muhakeme, sorumluluk. Zaten her şeyi bilemezsiniz." (12. Görüşmeci, 4 Ocak 2013)

Üçüncü olarak, sosyal kökenlerine baktığımızda, gerek aldıkları eğitim gerekse içinde bulundukları toplumsal ilişkiler ağı, köşe yazarlarını sosyo-ekonomik olarak da farklı konumlandırmamıza neden olmaktadır. Bunu belirleyen faktör ise "yeni burjuvazi" kavramının köşe yazarlığı alt-alanı faillerini tanımlamadaki önemiyle anlaşıır. Tarihi olarak köşe yazarlığı, gazete patronlarının ekonomik sermayesi ile edebiyatçıların kültürel sermayesinin bir harmanı olarak görülebilir. Bu bakımdan imtiyazlı çevrelerle sosyalleşme şansı bulan köşe yazarlarının sahip oldukları ve onlara sunulan ekonomik şartlar, gazetecilik alanının genelinde farklı bir tablo oluşmaktadır. "Yeni burjuvazi" kavramı da tam da bahsedildiği gibi memleketin aynı şehirlerinde yaşayan, şehir burjuvazisine dahil, kültürel sermaye birikimine sahip tüm farklı eğilimlerin kesiştiği ayrıcalıklı bir noktada meydana gelir (Rieffel, 1984).

\begin{abstract}
"Ben zaten yazı yazılan bir eve doğdum. Benim tanımadığım dedem, büyük dedem, bunlar zaten yazar, gazeteci, öğretmen, edebiyatçıydı. Babam da ben doğduğumda spor yazıları yazan, maç anlatan biriydi ama ben 6 yaşıma geldiğimde öldü. Ondan sonra da biz Basınköy'de bir gazeteci kooperatifinde, babam öldükten sonra, yaşadık. Orada büyüdüm. Orada etraf köşe yazarı doluydu. Çetin Altan, Orhan Kemal, Yaşar Kemal, başkaları. Ama çok mütevazı ortamlardı, herkes ahbaptı. Sonra üniversitedeyken hareketliydim, bildiri yazdım çok. Sendikada çalıştım, orada çok şey yazdım. Sonra Belediyeler Birliği'nde çalıştım. Hep yazı yazdım, araştırma yaptım. Çoğu da teksir bildirilerdi. Sonra 12 Eylül'den hemen sonra fiilen gazeteciliğe başladım, profesyonel. Muhabir, ekonomi şefi. Ekonomi şefiyken de küçük köşeler yazardım isimsiz. Yazı işleri müdürlüğü, genel yayın yönetmenliği yaptım. Genel yayın yönetmeniyken günlük köşe yazmadım asla bugünküler gibi. Sadece haftada bir, genel olarak medya, gazete üstüne bir şeyler yazdım. 1994 sonunda da istifa ettim. Ondan sonra sadece köşe yazdım. Milliyet'teydim, sonra kovuldum, bir ara üniversitedeydim hoca olarak, o ara Star'a yazı yolladım. Bu dördüncü gazete köşe yazarlığımda. Toplamda 17 sene sadece köşe yazarı olarak çalıştım. Gazetecilikte 35." (3. Görüşmeci, 4 Ocak 2013)
\end{abstract}

Köşe yazarlığı pratiğini, genel gazetecilik pratiklerinden ayıran faktörler, köşe yazısının üretim koşullarıyla ve biçimleriyle sınırlı değildir. Köşe yazarlığına içkin olan yapı aslında aktörlerin sosyalleşme mekanizmalarıyla da oluşur. Diyebiliriz ki, sahip olunan kültürel sermaye biçimlerinin, sosyalleşme mekanizmaları ve mekanları gibi sosyal sermaye belirleyicileri ile eklemlenmesi, köşe yazarlığı pratiğinin konumlandırımasında önemli oranda belirleyici olmaktadır.

"Bizim gibi adamlar, hareketli yaşıyor, oraya buraya davet ediliyor, konferanslara çağııılıyorsunuz, çok seyahat ediyorsunuz, çok temasınız oluyor, siyasilerle oluyor, toplumun içinde birçok insanla oluyor, kendiliğinden size bir takım şeyleri 
gönüllü olarak haber verenler çıkıyor. Dolayısıyla herhangi bir şeyi yazarken, gündemle ilgili bir konu, bir sürü aktörle zaten temasınız oluyor. Ya onlar size geliyor "Ben filanca gün İstanbul'dayım, bir sana uğrayayım" diyor. Bu bir bakan oluyor... Bazı bakanlar arkadaşımızdı o hükümetteki mesela (Özal hükümetini kastediyor). Okul arkadaşlarım filan var aralarında. Biri milletvekili oluyor, biri siyasetçi oluyor. Geliyor sohbet ederken, birtakım şeyler anlatıyor. Akşamları bilmem kimle yemeğe çıkıyorsunuz, ondan bir şey duyuyorsunuz. Dolayısıyla bilgi ve haber sirkülasyonunun sürekli içindesiniz zaten. O nedenle herhangi bir konuda, ama gündemin içinde bir konuda, gündemi etkileyen bir kalem olarak yazı yazacağınız zaman elinizde epey şey var. Un var, şeker var, su var, tuz var. Onu yapacaksınız. Malzeme var elinizde zaten." (Görüşmeci, 4 Ocak 2013)

Köşe yazarlığı pratiğine içkin olan sosyalleşme mekanizması, gazete mekânının dışında işlemektedir. Başka bir deyişle, bir muhabir sahaya çıkabilir fakat gazete mekânıyla fiziki bağı vardır çünkü en azından haber yazım süreci gazete mekânında gerçekleşir. Halbuki köşe yazarları için, sosyalleşme alanı gazete mekânı değildir. Her ne kadar medya şirketlerinin ve holdinglerinin özellikle İstanbul ve Ankara'da yoğunlaşmasıyla köşe yazarları da bu şehirlerde yoğunlaşmış olsa da, birçok köşe yazarının gazete bünyesinde ofisi dahi bulunmamaktadır ve gazete mekânıyla fiziki bağları oldukça zayıftır. Görüşülen 10 tam zamanlı çalışan köşe yazarından yalnızca iki kişinin gazete bünyesinde özel ofisi bulunmaktadır, geri kalan sekiz kişinin ise ya gazete bünyesinde ofisi bulunmamaktadır ya da ortak ofis alanları olmasına rağmen gazeteyle fiziki bağları yoktur.

\section{Köşe yazarlığının görece özerkliği}

Köşe yazarlığı pratiğinin gazetecilik alanından da, diğer toplumsal alanlardan da bağımsız olduğunu ya da tek taraflı bir bağımlılık ilişkisi içerisinde olduğunu iddia etmek yanlış olur. Köşe yazarlığı pratiği de tıpkı gazetecilik alanı gibi sonu olmayan bir özerklik arayışı içindedir. Patrick Champagne (1995, s. 128), gazetecilik alanının ikircikli yapısından bahsederken özerkliğin fethedilemeyen bir şey olduğunu söyler, çünkü gazetecilik alanı hem siyasi alana hem de ekonomik alana bağımlıdır. Bourdieu'nün de gazetecilik alanı çalışmalarında belirttiği gibi, gazetecilik alanı göreceli olarak özerk bir alandır çünkü gazetecilik alanı diğer kültürel üretim alanları arasında pazara, talebe ve siyasi alana en çok bağımlılık gösteren alandır (Bourdieu, 2008, s. 61). Dominique Marchetti de aynı mantıkla, bir alt-alanın özerklik derecesinin, ekonomik alanla ve siyasi alanla kurulan ilişsi üzerinden anlaşılabileceğini ve ölçülebileceğini söyler. Burada özerklik kavramından kasıt, birbiriyle ilişkide olan alt-alanların, nasıl birer "minyatür alan" (Marchetti, 2002, s. 24) gibi işlediğini göstermektir. Yani bir alt-alan olarak köşe yazarlığının özerkliği, medya alanındaki ve alanlar arasındaki konumuna bağlı olarak değişmektedir. Köşe yazarlığı pratiği hem kısıtlanan hem kısıtlayan, hem etkileyen hem etkilenen konumundadır. Bu pratiğin özerkliğini "göreceli" düşünmemiz bu sebeptendir. 
Köşe yazarlarının siyasi süreçlerde ne tür mekanizmaların işlevini üstlendikleri de simgesel iktidarlarının sınırlarını anlamak için açıklayıcı olabilir, çünkü simgesel iktidar temsil edildiği, kabul edildiği ve belli bir özgürlük alanı bulduğu ölçüde var olabilir. Köşe yazarlığı için toplumsal etki gücüne sahip, simgesel erk sahibi olan, kimi zaman yargı mekanizması olarak, kimi zaman siyasi ve toplumsal krizlerde bir başvuru mercii olarak işleyen bir müessese diyebiliriz. Bu tip bir kurumsallaşmanın simgesel boyutu çok güçlüdür, bu da bir köşe yazarının toplumsal ve siyasal meşruiyetiyle doğrudan ilgilidir. Köşe yazarları bulundukları pozisyona bağlı olarak, alanlar arası bir etki gücüne sahip olabildiği gibi, köşe yazarlarının bu etki gücünü kısıtlayabilen birçok faktör de olabilir. Gerçekleştiren görüşmelerde, köşe yazarlarına sorulan "Kendinizi ne ölçüde özgür hissediyorsunuz?" sorusuna verilen cevaplardan da anlaşılacağı gibi, gazete patronu, iktidar alanı ve medya çalışanları arasındaki ilişkiler, köşe yazarının toplumsal meşruiyeti, pozisyon ve argüman üretme kapasitesi gibi faktörler köşe yazarlığının özerklik derecesi iki yolla sınırlar; köşe yazarına yapılan doğrudan müdahale ve köşe yazarının uyguladığı otosansür.

\begin{abstract}
“Temel olarak evet ama bu yüzde yüz özgür değil malum. Yüzde yüz kimse özgür değil, hiç bir zaman da değildir. Bir kere babanızın malı bir gazetede yazmazsınız değil mi? Yazdığınız gazetenin bir yayın politikası vardır. Gazetenin hassasiyetleri vardır. Bu hassasiyetler sizi sınırlar. Mesela dindar bir gazetede yazıyorsanız, dinle ilgili ileri geri yazı yazmanız hoș karşılanmayacağı için siz o işe girmezsiniz. $\mathrm{Bu}$ biraz bulunduğunuz alanla kurduğunuz ilişkidir. Dolayısıyla yüzde yüz özgürlük size vermez. İkincisi tabii ülkenin siyasi koşulları önemlidir. Eğer ülkede demokratikleşme süreci daha baskınsa çok daha özgür olabilirsiniz ama tersine dönüyorsa iş, güvenlikçi bir atmosfer, daha otoriter bir koku ortaya çıkıyorsa tabii orada size gelen baskı hem hükümetten hem hükümetle iliş̧ide olan ya da ondan baskı gören gazete sahiplerinden, yayın yönetmenlerinden dolaylı olur. Ya rica edilir, ya siz bunu hissedersiniz, yazmazsınız. Kategoriler içerisinde değişiyor yazarlar. Kimisi çok dinler bu havayı, kimisi az dinler. Ben hep az dinleyenlerden oldum. Onun için de pek çok gazeteden atıldım. Mesleki açıdan köşe yazarı hiç bir zaman tam özgür olmamalıdır zaten. Türkiye gündemi, yazdığınız gazete, gazetecilik mesleği, etik... Pek çok kural sizin tam özgür olmanızı sınırlar. İkincisi yazdığınız ülke, gazete. Bütün bunlar da diğer faktörlerdir." (10. Görüşmeci, 2 Ocak 2013)
\end{abstract}

Köşe yazarlığının gazetecilik alanında bir "terfi makamı" hâline gelmesi ve buna bağlı olarak kamuoyu yaratma gücü ve sahip olduğu alanlar arası ilişki ağı köşe yazarının özerkliğini belirleyen faktörlerdendir. Aslında burada köşe yazarlığına içkin olan bir özellikten de bahsedilmektedir. Yani bir köşe yazarı sahip olduğu simgesel güç ve konum ölçüsünde hedef olabilme tehlikesiyle de karşı karşıya kalabilir. Buradaki temel kıstas, görüşülen köşe yazarlarının da belirttiği gibi, gazete prensiplerine ve siyasi atmosfere uygun yazılar üretmektedir. Hatta köşe yazarının kendi siyasi duruşuna uygun bir gazetede çalışması oluşabilecek engellerin önüne geçmek için faillerin tercih ettiği bir stratejidir.

"Gazetede bir sürü aleyhime işler yapıyorlardı, görmezden geliyordum. Ama sonunda 7'den 5'e indirdiler yazımı. O bende ciddi bir kırılma oluşturdu. Sonra 
da bir demecimi 'Yanlış anlaşıldım' deyip tashih etmemi istediler. Ben 30 yıllık hocayım. Bir şeyi yanlış söyleme gibi bir risk söz konusu değil benim için. Oradan da koptu. Ama zaten oraya doğru geliyordu hep. Yazılardaki eleştiri tonumdan çok huzursuzdular. O grubun televizyonuna çıkarmıyorlardı. Lehime hiçbir şey yoktu. Özgür olmadığım vakit yazmam zaten. Şu anda da durum onu gösteriyor." (7. Görüşmeci, 2 Ocak 2013)

Her köşe yazarının çalıştığı gazeteye göre uyması gereken, yazılı olmayan, içeriden veya dışarıdan belirlenmiş "kırmızı hatlara" dikkat etmesi, o köşe yazarının alan içi pozisyonun kalıcılığı için en temel koşullardan biridir. Köşe yazarının kamusal ve kişisel ahlak temelli bazı meselelere özen göstermesi beklenir ama özellikle gazetesini tehlikeye atmak istemeyen, iktidar alanıyla ilişkisini bozmak istemeyen gazete patronları, her ne kadar gazetelerinde çalışan köşe yazarıyla "ahbap" olsalar da ifade özgürlüğünü ekonomik ve siyasi çıkarlar lehine hiçe sayabilirler. Bu da köşe yazarına veya yazısına yapılan doğrudan müdahaleyle gerçekleşir.

"Genel olarak köşe yazarları, adı konarak ya da konmayarak, sınırlarını bilirler. Patronun kırmızı çizgileri nedir? Onun farkındadırlar. O zaman da o kırmızı çizgileri fazla zorlamazlar. Bazı köşe yazarları daha özerktir daha bağımsızdır. Çünkü ne bileyim kıdemlidir, geçmişleri, sicilleri dolayısıyla daha farklı yazarlar. Bunlara fazla karışılmaz ama onlar da dikkat ederler bazı şeylere. Ama dediğim gibi, neyi nasıl söyleyeceği de önemlidir. Ama ne kadar bağımsızdır dersen, değillerdir. Orada tabii, gazete yöneticileri 'bu yazı girmez' derler. Neden girmez? Ankara'yı rahatsız eder çünkü, neden girmez bu askeri rahatsız eder, neden girmez patronun iş ilişkileriyle ilgili bir şeyi etkiler, neden girmez bu başbakanı rahatsız eder." (2. Görüşmeci, 7 Ocak 2013)

Köşe yazarlığına has olan söylem ve dil kullanım stratejileri aslında köşe yazarının özerklik derecesini belirleyen bir durum yaratır. Yukarıda görüşmecinin bahsettiği gibi, "üslup", müdahale sınırlarını iyi yönde belirleme gücüne sahip olsa da bunu farkında olmak ve buna uygun yazmak aslında içselleştirilmiş bir otosansür tavrının varlığının göstergesidir. Dolayısıyla alan içi pozisyonun sürekliliği için yazılı ve görsel basında köşe yazarlarının benimseyeceği stratejiler, doğrudan özerklilerinin göreceliliğini korumaya yöneliktir. Fransa'da köşe yazarları üzerine çalışan Philippe Riutort, köşe yazarlarının, hem gazetecilik alanındaki yüksek konumlarından dolayı hem de köşe yazarlığı bir "uzaktan gazetecilik" biçimi olduğu için diğer bilgi üreten mesleklere kıyasla daha az baskıya maruz kaldığını söyler. (Riutort, 1996). Fakat bu durum Türkiye gibi demokratikleşme sürecini tamamlayamamış ülkelerde, siyasi atmosfere bağlı olarak, geçerli olmayabilir. Zira araştırma kapsamında görüştügüumüz üç köşe yazarı, görüşmelerin hemen akabinde işten çıkartılmış, uzun bir süre sosyal medya aracılığı ile varlıklarını sürdürmüşlerdir. 


\section{Sonuç}

Köşe yazarlığı siyaset-medya ilişkisi çerçevesinde de tanımlanabilecek olan, kamuoyunu yönetebilen ve kamuoyu oluşturabilen simgesel bir güç ve kültürel bir üretim kurumudur/alanıdır. Özellikle 1980'lerden günümüze yaşanan ekonomik dönüşüm sürecinde köşe yazarlığı pratiğinin medya hiyerarşisindeki konumu pekiştirmesi ve kurumsallaştırmasıyla ortaya çıkan yapısal farklııklar önemlidir. Pratiğin alan içerisindeki pozisyonu, bilginin üretim koşulları, faillerin özellikleri ve sosyalleşme mekanizmaları gibi kriterler aracılığıyla diğer gazetecilik pratiklerinden ayrışan köşe yazarlığı pratiğine bu gözle bakmak, medya sosyolojisi çalışmalarına katkı sağlayacaktır. Ayrıca köşe yazarlığının, gazetecilik hiyerarşisinde sahip olduğu pozisyon gereği, sahip olduğu özerkliğin göreceli olma nedenleri de pratiği farklılaştıran faktörler arasında aranmalıdır.

Köşe yazarları/yazarlığı evreni/alanı oldukça heterojen, kendi içinde de farklılıklar barındıran bir evrendir. Bu sebeple, köşe yazarlarına veya köşe yazarlığı pratiğine yönelik kategoriler sunmak oldukça güçtür. Köşe yazarlığının medya hiyerarşisinde sahip olduğu imtiyazlı konum, bu pratiğin her zaman imtiyazlı olduğu anlamına da gelmemektedir. Farklı etkileşimlerin ve karşılıklı bağımlılıkların bulunduğu bir noktada yer alan köşe yazarlığı pratiğinin çatışmacı ve çatışma doğuran bir karakteri olduğunu da unutmamak gerekir. Bir yandan siyaset yazan köşe yazarlarının özellikle sahip oldukları imtiyazlı konumdan haberdar olmaları buna karşı stratejiler geliştirmelerine yol açmıştır ki bu onlara yapılan doğrudan müdahaleleri her zaman engellemez. Bu stratejiler, söylem ve dil düzeyinde olabildiği gibi (kelime oyunları, farklı anlatı biçimleri gibi), otosansür şeklinde de görülebilmektedir. Öte yandan köșe yazarları, kamuoyunu yönlendirmedeki rolleri düşünüldüğünde, "ateş körükleme" potansiyeline de sahiptir, özellikle siyasi kriz, kutuplaşma dönemlerinde köşe yazarlarının rolü oldukça yönlendirici olabilmektedir. Köşe yazarlarının kamuoyunu oluşturma ve yönlendirme potansiyeli, çoğu zaman alanlar arası bir etki yaratmakta, yarattığı etki ölçüsünde köşe yazarının özerklik alanı kısıtlanmaktadır.

Köşe yazarlığı pratiği yapısı gereği, özellikle Türkiye'de gazetecilik alanının bir özgünlüğüdür diyebiliriz. Köşe yazarları, bilginin üretim koşulları ve medya piyasasına entegre olma biçimleriyle birçok gazetecilik alanı aktöründen ayrılmaktadırlar. Özellikle köşe yazarları konusunda faillerin sahip olduğu sosyal ve kültürel sermayenin zaman içerisinde ekonomik ve simgesel sermayeye dönüşüyor olması bu araştırmanın özgün fikirlerinden biridir. Faillerin medya alanındaki ve alanlar arasındaki dolaşımı için de gerekli olan sosyal sermaye ve kültürel sermayenin büyük ölçüde köşe yazarlarının haber kaynaklarının kaynağını oluşturduğunu söylemek yanlış olmayacaktır. Bu durum hem köşe yazarlığını medya alanı hiyerarşisinde yükseklere çıkarmakta, öte yandan köşe yazarlığını bir çatışma alanı olarak ortaya çıkarmaktadır. Üretilen bir bilgi/yorum türü olarak köşe yazısı türü, gazetecilik alanı haber-bilgi türleri arasında farklı bir konuma sahiptir ki bu durum, anonim ve yayın ilkeleri dahilinde haber yayınlayan muhabirlerle, köşe 
yazarları arasına mesafe koyan bir durum oluşturur çünkü köşe yazısının fotoğraflıimzalı hâli, köşe yazarının toplumsal bir figür olarak karşımıza çıkmasına neden olur. Böylece köşe yazarlığı kurumsallaşarak, topluma da mal olmuş olur. Köşe yazarlığının kurumsallaşan bir yapı olarak işlemesinin bir başka nedeni ise, failleri tarafından içselleştirilmiş birtakım değerlerin ve normların varlığıdır. Bu değer ve normlar, kişisel olmaktan öte, gazetelerin yayın politikalarına ve yönetimlerinin yapısına göre değişmektedir. Bu noktada köşe yazarlarının alan içi konumlarını korumak için söylem düzeyinde stratejiler geliştirdiğinin altını çizmek gerekir. Bu çalışmada en öne çıkan strateji ise otosansürdür ki bu fikir/yorum gazeteciliğinin var olma sebebine aykırı bir durum oluşturur.

Bu makalede, gazetecilik pratiklerinden bir çok açıdan farklılaşan köşe yazarlığı pratiği üzerinde durulmuştur. Köşe yazarlarının, bilgiyi ve yorumu üretme koşulları ve faillerin sosyalleşme mekanizmaları ve sermaye birikimleri köşe yazarlığı pratiğini büyük ölçüde kendine özgü bir pratik olarak ele almamızı gerektirmiştir. Makalenin amacı, köşe yazarlığı pratiğinin ideal tanımını sunmak değil, farklılaştığı noktalar üzerinde durarak, bu pratiği gazetecilik alanının bir altalanı olarak düşünmeyi sağlamaktır. "Kanaat önderi", veya "kamusal entelektüel" söylemlerinden ziyade, bu pratiğin toplumsal olarak farklı konumlandırılmasının nedeni üzerinde düşünmek, bu pratiğin içinde barındırdığı yapısal sorunları da göstermektedir.

\section{Kaynakça}

Bali, R. (1999). Yeni Aristokratlar; Köşe yazarları, Birikim, 117, 57-60.

Bilgin, F. (2003). Köşe Yazarlarının 11 Eylül Olaylarına Yaklaşımı. Yayınlanmamış Yüksek Lisans Tezi. Kocaeli Üniversitesi Sosyal Bilimler Enstitüsü. Kocaeli.

Bora, T. ve Cantek, L. (2009). Köşe Yazarlığındaki Değişim ve Politik Düşünce Vasatı, Modern Türkiye'de Siyasi Düşünce içinde, Cilt:9, Dönemler ve Zihniyetler, İstanbul : Illetişim Yayınları.

Bourdieu, P. (2008). Sur la télévision, Paris: Raison d'agir.

- (2002). Questions de sociologie, Paris: Les édition de Minuit.

- (2000). Esquisse d'une théorie de la pratique, Paris: Editions de Seuil.

- (1993). The Field of Cultural Production, Cambridge: Polity.

- (1979). La Distinction: Critique social du jugement, Paris: Éditions de Minuit.

- (1980). Le sens Pratique, Paris: Editions de Minuit.

- (1986). The forms of capital, Richardson, J., Handbook of Theory and Research for the Sociology of Education, Westport, CT: Greenwood 
Bölükbaşı, i. (2002). Avrupa Birliği Sürecinde Farklı Ideolojik Kamplardaki Gazete ve Köşe Yazarlarının Yaklaşımları Üzerine Bir Inceleme. Yayınlanmamış Yüksek Lisans Tezi. Ankara Üniversitesi Sosyal Bilimler Enstitüsü. Ankara.

Charaudeau, P. (2009). Identité sociale et identité discursive. Un jeu de miroir fondateur de l'activité langagière, Identités sociales et discursives du sujet parlant içinde, Paris: L'Harmattan.

Champagne, P. (1995). La double dépendance. Quelques remarques sur les rapports entre les champs politique, économique et journalistique, Hermès, 1718, 215-229.

Dubied, A. ve Lits, M. (1997). L'éditorial : genre journalistique ou position discursive?, in Pratiques 94, 49-61

Durna, T. (2002). Türk Basını'nda Avrupa Birliği: Köşe Yazılarında Adaylık Sürecinin Sunumu (3-24 Aralık 1999). Yayınlanmamış Yüksek Lisans Tezi. Ankara Üniversitesi Sosyal Bilimler Enstitüsü. Ankara.

Dursun, O. (2015), Köşe Yazarlığından Medya Filozofluğuna: Ertuğrul Özkök ve Ahmet Hakan'ın Köşe Yazıları üzerine bir inceleme. Hacettepe Üniversitesi Sosyolojik Araştırmalar E-Dergisi, Erişim 4 Kasım 2016. http://www.sdergi. hacettepe.edu.tr/makaleler/KoseYazarligindanMedyaFilozofluguna-MART_2015. pdf.

Ercan, G. (2003). Gazete Köşe Yazılarında Dil Kullanımı: Kaçınmalar ve Cinsiyet Değişkeni. Yayınlanmamış Yüksek Lisans Tezi. Dokuz Eylül Üniversitesi Sosyal Bilimler Enstitüsü. İzmir.

Koloğlu, O. (1994). Osmanlı'dan Günümüze Türkiye'de Basın. İstanbul: İletişim.

Marchetti, D. (2002). Les sous-champs spécialisés du journalisme, Réseaux, $111,22-55$.

Martin-Lagardette, J. (1994). Guide de l'écriture journalistique. Écrire, informer, convaincre, Paris:Syros.

Mehmet, E.(2002). Spor Gazeteciliğinde Nesnellik: Fanatik, Fotomaç Spor Gazeteleri ve Star Gazetesi Köşe yazıları lç̧erik Çözümlemesi. Anadolu Üniversitesi Sosyal Bilimler Enstitüsü. Yayınlanmamış Yüksek Lisans Tezi. Eskişehir.

Mert, Nuray. (26 Ağustos 2004). Köşe Yazarlığı, Radikal.

Özdemir, E. (1999). Yazınsal Türler. 4. Baskı. Ankara: Bilgi Yayınevi.

Özdemir, E. (2002). Edebiyat Bilgileri Sözlüğü .İstanbul: Remzi Kitabevi.

Özkök, E. (4 Mayıs 2014). Üç Bin Köşe Yazarı Varmış, Hürriyet.

Reuteurs. (2008). Handbook of journalism. Erişim: http://www.trust.org/ contentAsset/raw-data/652966ab-c90b-4252-b4a5-db8ed1d438ce/file 
Rieffel, R. (1983). Analyse de l'élite des journalistes. Questions de méthode. Revue française de science politique. 3, 455-479.

Riley, S. G. (1998). The American Newspaper Columnist. Westport : CT, Praeger Publishers.

Riutort, P. (1996). Grandir l'événement. L'art et la manière de l'éditorialiste. Réseaux, 76 , 61-81.

Tılıç, D. (2009). Utanıyorum ama gazeteciyim, İstanbul: İletişim.

Topuz, H. (2003). Türk Basın Tarihi. İstanbul: Remzi Kitabevi.

Ülgener, S. (1983). Zihniyet, Aydınlar ve Izm'ler, İstanbul: Derin Yayınları.

Yüce, E. (2007). Simgesel Seçkinler Ve Habitus: Hürriyet Gazetesi'nde Köşe Yazarlığı, Yayınlanmış Yüksek Lisans Tezi. Ankara Üniversitesi, Sosyal Bilimler Enstitüsü. Ankara.

Tezel, M. (2 Mayıs 2008). İstanbul'da 400 köşe yazarı var, ya Amerika'da?, Hürriyet.

Tunç, A. (2012). Köşe yazarları neden var?, Erişim: 23.05.2013, http://www. habervitrini.com/haber/kose-yazarlarinin-cogu- gereksiz-91851/. 